\title{
Charakteristiky určující stabilitu říčního dřeva na príkladu Moravy v Litovelském Pomoraví
}

\section{PAVEL KOŽENÝ}

\author{
Klíčová slova: říční dřevo - povodně - řeka Morava - CHKO Litovelské Pomoraví - logistická regrese
}

\section{SOUHRN}

Říční dřevo je významnou součástí vodních toků, ve kterých ovlivňuje hydraulické, morfologické i biologické vlastnosti. Pro potřeby správy vodních toků a omezení povodňových rizik je důležité znát faktory, které zvyšují stabilitu dřeva a brání jeho odplavení při zvýšených průtocích. Na základě analýzy vlastností 160 kusů ríčního dřeva v korytě Moravy v CHKO Litovelské Pomoraví byly zjištěny charakteristiky významné pro stabilitu ř́čního dřeva $v$ této oblasti. Analýza byla provedena logistickým regresním modelem a jako statisticky významné identifikovala následující charakteristiky: délka kmene, výška uložení vưči běžné hladině, míra zazemnění, př́tomnost kořenů a rozlišení, zda jde o kmen živý či odumřelý. Aplikací modelu na konkrétní kus Ize vypočítat modelovanou pravděpodobnost stability. Pokud je z důvodů zachování přirozeného stavu koryta požadováno ponechání stabilních kusů rričního dřeva, měly by být tyto charakteristiky respektovány. Modelované pravděpodobnosti korelovaly se subjektivním odhadem stability s koeficientem determinace $R^{2}=0,57$.

\section{ÚVOD}

Termínem říční dřevo označujeme stromy a jejich části, které se přirozenými způsoby nebo činností člověka dostaly do koryta vodního toku a vstupují zde do interakce s vodním proudem [1]. Říční dřevo ovlivňuje hydraulické podmínky v korytě, formuje jeho tvar a vytváři pestrou nabídku stanovišt pro vodní organismy [2]. Dřevo je dynamickou složkou říčních krajin. Vstupuje do koryta různými prísunovými mechanismy, mění svou polohu, je unášeno povodněmi a znovu zachycováno v jiných úsecích koryta. V průběhu času může zcela podlehnout rozkladu, může být vyplaveno do nivy nebo být pohřbeno $v$ říčních náplavech. Pohyblivosti říčního dřeva při povodních je věnována pozornost mimo jiné z důvodu údržby vodních toků a prevence povodňových rizik.

Z minulých desetiletí existuje řada výzkumných prací, které se mobilitou říčního dřeva zabývají. Deskriptivní prístupy vycházejí z popisu množství a charakteru dřeva na lokalitě, tvaru a výskytu akumulací naplaveného dřeva i stabilních kusů v jejich základech [3-5]. Experimentální studie značeného dřeva v terénu umožnily posouzení vlivu konkrétních průtoků v definovaných časových úsecích. Značené kusy mohly být dohledány a byly zkoumány parametry ovlivňující jejich transport [6-12]. Teorie o vlastnostech mobilizace, transportu a zachytávání idealizovaných modelư ríčního dřeva byly ověřovány experimentálně $\vee$ hydraulických laboratořích i v terénu [13-15]. V posledních letech jsou sestavovány matematické modely popisujíci dynamiku dřeva v rámci dlouhých úseků toků nebo povodí. Časté jsou také zcela praktické studie zabývající se náchylností inženýrských staveb k zachytávání vodou unášeného plovoucího materiálu [16-18].
Výzkumy provedené v minulosti ukázaly, že kromě průtokových charakteristik vodního toku je stabilita říčního dřeva ovlivňována především jeho rozměry relativně k šírce a hloubce koryta. Stabilitu také významně zvyšují zachovalé kořeny, kořenový bal a větve. Poloha kmene v korytě a jeho orientace vůči proudění jsou též významné parametry, které navíc souvisejí se stabilizačními mechanismy brehové vegetace a stabilitou rozměrných akumulací říčního dřeva. Ačkoliv jsou uvedené poznatky obecně platné, každá lokalita je specifická svými prírodními podmínkami, které je třeba pro praktický management říčního dřeva zohlednit.

$\checkmark$ této studii je popsána identifikace parametrů, které jsou významné pro stabilitu říčního dřeva v meandrujícím korytě v podmínkách tvrdého luhu střední Evropy. Tato práce vychází z prededpokladu, že analýzou stávajícího říčního dřeva Ize $v$ určitém typu prírodního území poměrně snadno určit parametry, které jsou v daném prostředí pro stabilitu dřeva rozhodující. Pokud dokážeme rozlišit mezi drevem, které se korytem $v$ minulosti pohybovalo, a kusy ríčního dřeva, které se vyskytují na původním místě svého přísunu do koryta, můžeme si udělat představu o charakteru dřeva, které je v daném území stabilní. Dílčí studovanou otázkou též byla shoda mezi subjektivním odhadem stability a pravděpodobností stability vypočítané na základě analýzy řičního dřeva.

\section{METODY}

\section{Lokalita}

Terénní výzkum proběhl na řece Moravě u Litovle na lokalitě zvané Vrapač $\left(49.7140^{\circ} \mathrm{N}, 17.0340^{\circ} \mathrm{E}\right)$. Řeka Morava je zde tokem sedmého rádu podle Strahlera s průměrnou šířkou koryta 28 metrů a plochou povodí 2144 km². Pro blízký profil v Moravičanech udává Český hydrometeorologický ústav průměrný průtok $17,1 \mathrm{~m}^{3} \cdot \mathrm{s}^{-1}$. Dno řeky je převážně štěrkové, břehy tvoří vrstvy povodňových hlín silné přes dva metry. Povrch říční nivy se nachází v nadmořské výšce kolem $230 \mathrm{~m}$ n. m. Neupravené koryto Moravy u Vrapače prodělává již desítky let zrychlený geomorfologický vývoj, který je následkem zvýšení spádu na kontaktu s regulovaným korytem nad Litovlí. Dnešní sklon koryta v úseku Vrapače je v průměru 2,4\%o. To je více než na zbytku Moravy mezi jezem Řimice a Litovlí, jehož sklon je v rozmezí 0,6-0,9\%o. Kromě postupného zahlubování se zvýšení spádu projevuje výraznou boční erozí a rozmeandrováním koryta v úseku dlouhém téměř 1 kilometr. Průvodním jevem rychlého ústupu břehů v nárazových obloucích meandrů je postupné sesouvání stromů z břehového porostu do koryta. Lokalita je charakteristická bohatým přisunem místní (autochtonní) dřevní hmoty i akumulací ríčního dřeva splaveného z výše položených úseků toku. Druhová struktura říčního dřeva odpovídá tvrdému luhu, kterým je řeka 
obklopena. Převládá v něm jasan, dub, javor a lípa. Z nižších partií nivy se do reky dostávají části vrb a výjimečně topolů. Ze vzdálenějších částí povodí jsou splavovány též části olšových kmenů a ojediněle zbytky jehličnanů. Většina řícního dřeva na lokalitě má pririrozený původ (vývraty, zlomy). Na lokalitě byla $\checkmark$ roce 2003 provedena stabilizace ríčního dřeva v podobě ukotvení 70 vzrostlých stromů ocelovými lany [19]. Po roce 2010 však počet zachovalých kotvených kmenů klesl na minimum a neovlivňoval nijak významně akumulaci naplaveného dřeva nebo stabilitu okolních nekotvených kmenů. Několik zbývajících kotvených kmenů, které se na lokalitě vyskytovaly v roce 2014, nebylo do evidence říčního dřeva zahrnuto.

\section{Popis ř́čního dřeva}

Pokud nás zajímají vlastnosti říčního dřeva, které je v podmínkách dané lokality stabilní, lze to zjistit analýzou stávajícího dřeva na lokalitě, pokud dokážeme u jednotlivých kusů určit, zda se v korytě pohybují, nebo zůstávají po dlouhou dobu na místě. S jistou mírou zjednodušení můžeme autochtonní říční dřevo v této studii považovat za kusy stabilní přinejmenším za období několika posledních let. Naopak naplavené dřevo by mělo být charakterizováno vlastnostmi, které jsou typické pro nestabilní kusy běžně unášené povodněmi. Tato studie proto považuje kategorie autochtonní/naplavený za analogické pro stabilní/nestabilní říční dřevo. V dalším textu tyto termíny používám s vědomím této analogie.

Tabulka 1. Prehled charakteristik použitých pro popis řícního dreva a jejich hodnoty Table 1. List of the characteristics used to describe the woody debris and their values

\section{Proměnná}

Popis

\section{Jednotky}

\begin{tabular}{|c|c|c|c|}
\hline AUTOCH & autochtonní/naplavený kmen & třídy: A - autochtonní, $\mathrm{N}$ - naplavený & $A: 96 ; N: 64$ \\
\hline NAD_HL & $\begin{array}{l}\text { výška uložení středu kmene nad běžnou } \\
\text { hladinou }\end{array}$ & $\mathrm{cm}$ & $14,7(-30 ; 40)$ \\
\hline ZAZEM & procento zazemnění kmene do dna nebo břehu ${ }^{1}$ & $\%$ & $14,8(0 ; 20)$ \\
\hline ZIVY & A - kmen živý, X - kmen suchý & třídy: A - živý, X - suchý & $A: 13 ; X: 147$ \\
\hline KORUNA & prítomnost koruny nebo silných větví & trídy: A - s korunou, X - bez koruny & A: 64; X: 96 \\
\hline KORENY & př́tomnost kořenů & třídy: A - s kořeny, X - bez kořenů & A: $100 ; X: 60$ \\
\hline SAMOST & uložení samostatně nebo v akumulaci & $\begin{array}{l}\text { trídy: S - samostatně, } \\
\text { A - v akumulaci }\end{array}$ & S: 54; A: 106 \\
\hline PRUMER & průměr kmene v polovině délky & $\mathrm{cm}$ & $25,6(19 ; 30)$ \\
\hline DELKA & délka kmene & $\mathrm{m}$ & $11,6(5,3 ; 16,4)$ \\
\hline ROZKLAD2tr & stupeň rozkladu & trídy: $0-3 ; 3,5-5^{2}$ & $0-3: 142 ; 3,5-5: 18$ \\
\hline KORYTO2tr & poloha kmene na prričné ose koryta & trídy: $1-2 ; 3-5^{3}$ & 1-2: 141; 3-5: 19 \\
\hline ORIENT1 & orientace osy kmene vůči vodnímu proudu & třídy: $150^{\circ}-210^{\circ}$, jiné ${ }^{4}$ & $150^{\circ}-210^{\circ}: 71 ;$ jiné: 89 \\
\hline STAB_SUBJ & míra subjektivně stanovené stability kmene & třídy: $1-10^{5}$ & $5,6(3 ; 9)$ \\
\hline
\end{tabular}

'Pokud nebyl kmen viditelnýv celé délce, byla jeho délka konzervativně odhadnuta podle délek kmenů odpovídajicího průměru vyskytujicích se na lokalitè. If the log was not visible in its entire length, its length was conservatively estimated according to other wood of the same diameter occurring at the locality.

${ }^{2}$ Trídy stupně rozkladu: 0 - čerstvě vyvrácený živý strom, 1-zachovalé drobné větvičky a pevná kưra, 2 - zachovány silné větve, kưra volná, 3 - bez kưry, drevo pevné, 4 - drevo částečně zetlelé, 5 - drevo prevážně zetlelé. Pro analýzu byly třídy stupně rozkladu agregovány do dvou skupin.

Wood decay class: 0 - recently uprooted living tree, 1 - small twigs present, firm bark, 2-large branches present, loose bark, 3- no bark, solid wood, 4- partially decayed wood, 5 - mostly decayed wood. For the analysis decay classes were aggregated into two groups.

${ }_{3}^{3}$ Trídy polohy kmene na přičné ose koryta: 1 - ve vodě v proudnici, 2 - ve vodě mimo proudnici, 3 - přechod voda/souš, 4 - svah břehu (souš), 5 - okraj břehové hrany. Pro analýzu byly trídy agregovány do dvou skupin.

Class of wood position on the transverse axis of the stream channel: 1 - in water in a streamline, 2 - in the water, off the streamline, 3- transition water / stream bank, 4 stream bank (land), 5 - upper edge of bankfull channel. For analysis classes were aggregated into two groups.

${ }^{4}$ Orientace osy $180^{\circ}$ znači polohu, kdy je kmen paralelněs proudem, špička směruje po proudu, kořeny proti proudu, $0^{\circ}$ - kmen paralelněs proudem, špička směruje proti proudu, $90^{\circ}$ - kmen kolmo k proudu, špička sméřuje od břehu, $270^{\circ}$ - kmen kolmo k proudu, špička směruje ke břehu. Pro analýzu byla orientace agregována do dvou tříd. Orientation of $180^{\circ}$ is the position where the tree is deposited parallel to flow direction, the treetop is downstream, roots are upstream, $0^{\circ}$ - the tree is parallel to the flow direction, the treetop is upstream, $90^{\circ}$ - tree is perpendicular to the flow direction, treetop directed from the bank, $270^{\circ}$ - tree is perpendicular to the flow direction, treetop directed to the bank. ${ }_{5}^{5}$ Trídy subjektivně stanovené stability kmene: 1 - minimální stabilita, 10 - maximální stabilita.

Class of subjectively estimated wood piece stability: 1 - minimum stability, 10 - maximum stability. 


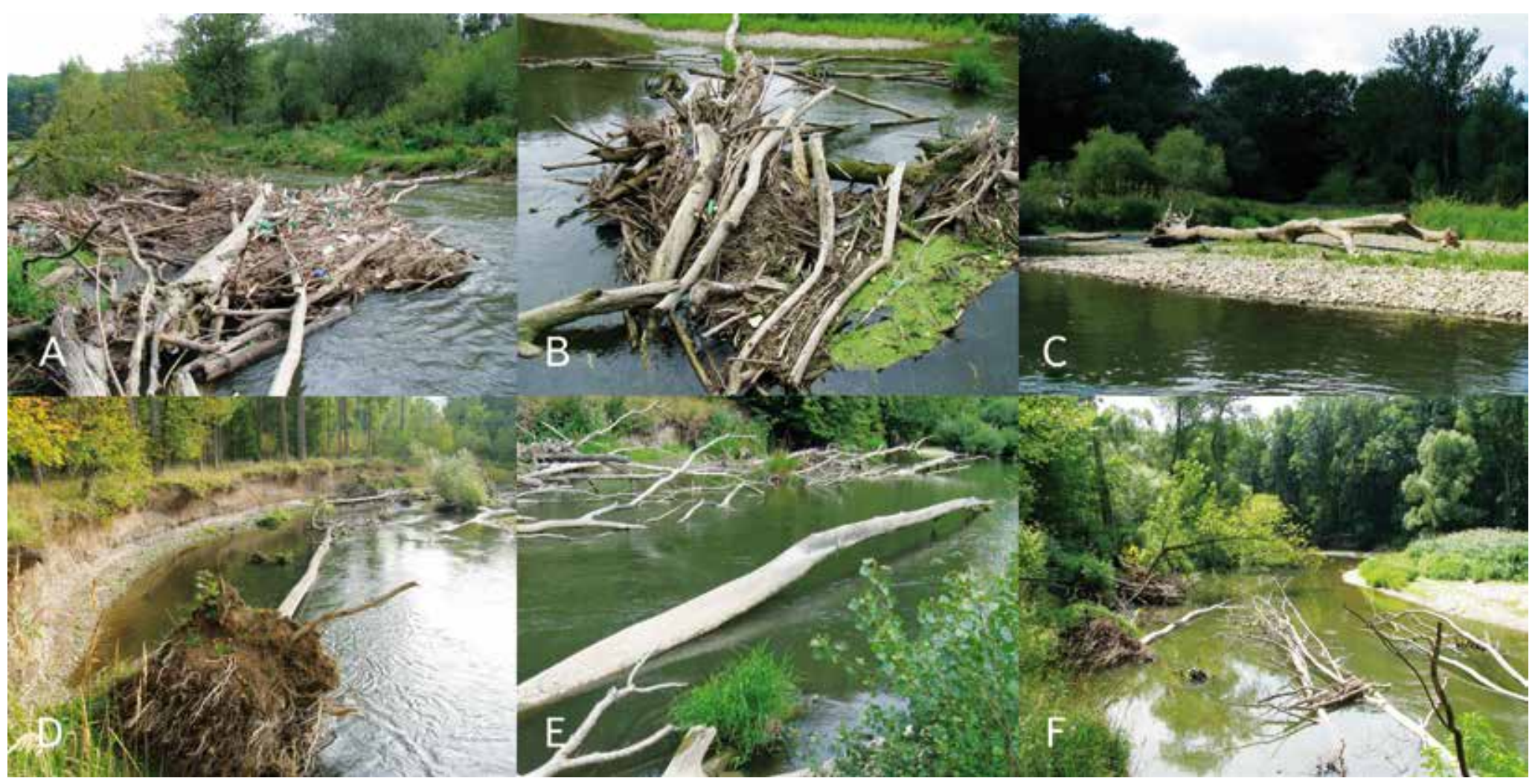

Obr. 1. Př́klady říčního dřeva v řece Moravě na lokalitě Vrapač v CHKO Litovelské Pomoraví; A-C: naplavené kusy, D-F: autochtonní kusy

Fig. 1. Examples of wood in Morava River at the Vrapač locality, Litovelské Pomoraví PLA; A-C: allochthonous pieces, D-F: autochthonous pieces

Popis řičního dřeva probíhal na zmíněné lokalitě v řijnu 2014. Na úseku dlouhém přibližně 700 metrů, zahrnujícím čtyři meandrové oblouky, bylo popsáno vyskytující se rríční dřevo od délky dvou metrů a průměru $10 \mathrm{~cm}$. Dřevo bylo popisováno v celém rozsahu koryta, tedy až po okraj břehové hrany. Popis proběhl v období nízkých průtoků, kdy bylo koryto z více než $95 \%$ broditelné. Pro každý jednotlivý kus říčního dřeva byly zaznamenány charakteristiky velikosti, tvaru a stupně rozkladu. Dále byla zaznamenána poloha v korytě, poloha vůč ostatním kusům řičního dřeva a orientace vưči směru proudění. Před statistickou analýzou byl rozsah tříd kategoriálních proměnných agregován, abychom získali třídy s dostatečnými četnostmi pozorování. Přehled popisných charakteristik je uveden $v$ tabulce 1 .

U každého kusu bylo rovněž posouzeno, zda jde o kus naplavený, nebo uložený v místě svého vzniku (tzv. autochtonní). Určení bylo provedeno pomocí vzhledu kmene (např. způsob a vyšší míra abraze u naplavených kusů) a jeho pozice (např. výskyt v akumulaci zjevně naplaveného dřeva, na štěrkových lavicích mimo potenciální místa prísunu, při březích bez stromové vegetace atd.) nebo na základě stop v terénu (např. bezprostředně související břehová nátrž). Identifikaci autochtonních kmenů usnadňovala skutečnost, že u meandrujících toků je hlavním prísunovým mechanismem břehová eroze [1]. Příklady říčního dřeva vyskytujícího se na lokalitě přibližuje obr. 1. Mezi naplavené byly zařazeny kmeny, které se posunuly alespoň o 25 metrů od pravděpodobného místa přísunu do koryta. Rozlišení na autochtonní a naplavené ríční dřevo bylo provedeno bez ohledu na čas, který uplynul od přemístění naplaveného kusu nebo prísunu autochtonního kusu ze břehu. To znamená, že jako naplavený byl označen i kmen, který se přesunul při jedné povodňové epizodě $v$ minulosti a v nové pozici již zůstal po řadu let.

Poslední zaznamenávanou charakteristikou byl subjektivní odhad stability popisovaného kusu, tedy odolnost vưči odplavení při povodních. Hlediskem pro posouzení byly informace z literatury a víceletá zkušenost autora s dynamikou rríčního dřeva na lokalitě. Tato charakteristika souvisí do značné míry s popisovanými vlastnostmi říčního dřeva, ale jejich souhrnné hodnocení pro daný kus bylo rychlým subjektivním odhadem. Analýza tohoto odhadu probíhala proto odděleně od ostatních, objektivně hodnocených charakteristik. Subjektivní odhad stability napodobuje terénní odhad, který by na základě místní zkušenosti mohl provádět napríklad pracovník pověřený správou vodního toku.

\section{Statistická analýza terénních dat}

Analýza dat spočívala v určení nezávislých popisných charakteristik, které jsou významné pro rozlišení mezi autochtonními a naplavenými kusy říčního dřeva (proměnná AUTOCH). Vzhledem k povaze získaných dat, kdy závislá proměnná nabývá pouze dvou hodnot (autochtonní/naplavený, resp. stabilní/nestabilní), byla pro statistickou analýzu zvolena logistická regrese. Logistický regresní model popisuje pravděpodobnost $P$ zkoumaného jevu za podmínek daných hodnotami nezávislých proměnných $x$. Vyjadřujeme jej rovnicí:

$$
\ln \left(\frac{P^{(x)}}{1-P^{(x)}}\right)=\beta_{0}+\Sigma_{i} \beta_{i} x_{i}
$$

kde $P$ je pravděpodobnost, že nastane zkoumaný jev,

$x \quad$ vyjadřuje hodnoty nezávislých proměnných,

$\beta_{0}$ a $\beta i \quad$ koeficienty regresního modelu. 
Ekvivalentně Ize tento model vyjádřit rovnicí:

$$
p(x)=\frac{\exp \left(\beta_{0}+\sum \beta_{i} x_{i}\right)}{1+\exp \left(\beta_{0}+\sum \beta_{i} x_{i}\right)}
$$

Protože hodnoty koeficientů $\beta$ jsou výsledkem logistického regresního modelu, můžeme po dosazení hodnot proměnných $x$ vypočítat pravděpodobnost $P$, s jakou nastane zkoumaný jev [20].
Výběr vhodných proměnných a tvorba logistického regresního modelu probíhala $\vee$ několika krocích. $\vee$ první fázi byla závislá proměnná AUTOCH modelována vždy jen pomocí jedné z popisných charakteristik. Výsledek tohoto tzv. univariantního modelu naznačil, které z popisných charakteristik jsou významné pro zařazení kusu mezi autochtonní či naplavené říční dřevo. Zároveň byly zhodnoceny prípadné závislosti mezi popisnými charakteristikami pomocí grafů, korelační matice a hodnot VIF (variance inflation factor). Do další analýzy byly zařazeny pouze charakteristiky, které univariantní model určil jako významné pro stabilitu říčního dřeva a zároveň tyto proměnné nebyly

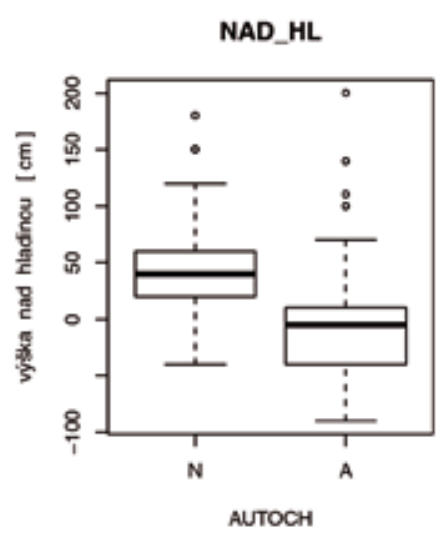

DELKA

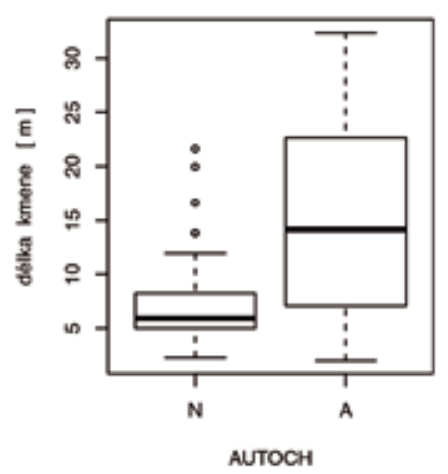

SAMOST

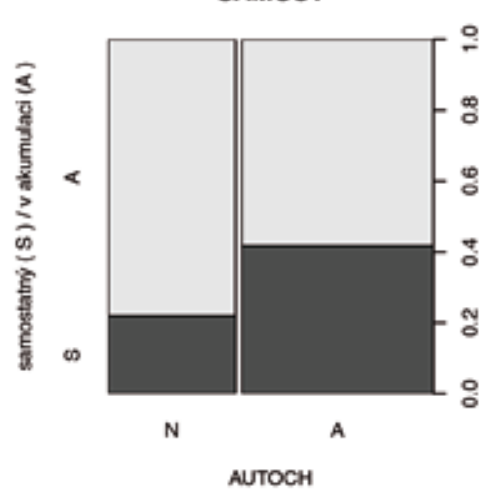

ZAZEM

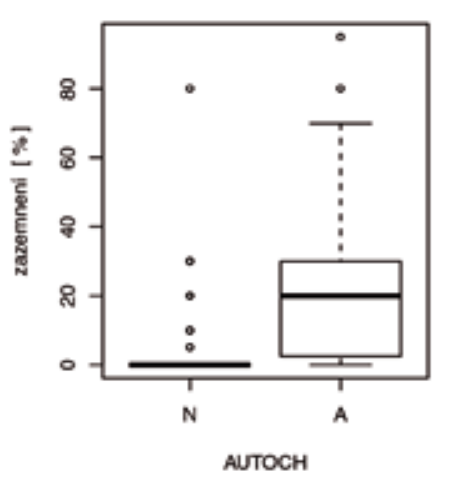

ZIVY

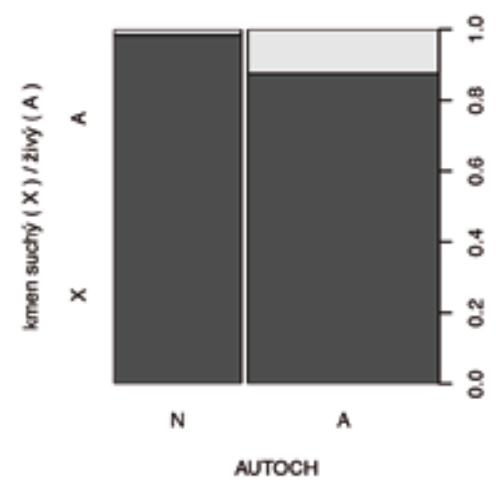

ROZKLAD2tr

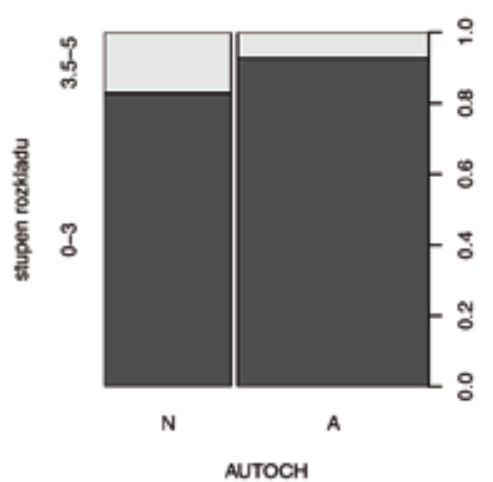

STAB_SUBJ

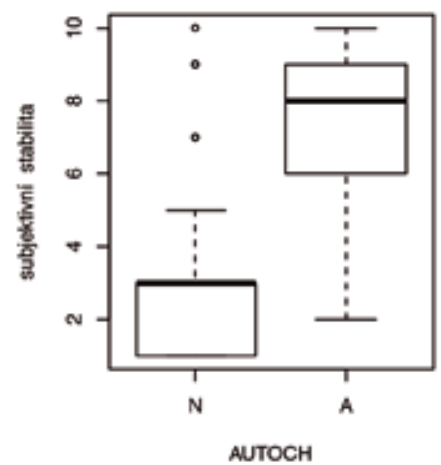

KORUNA

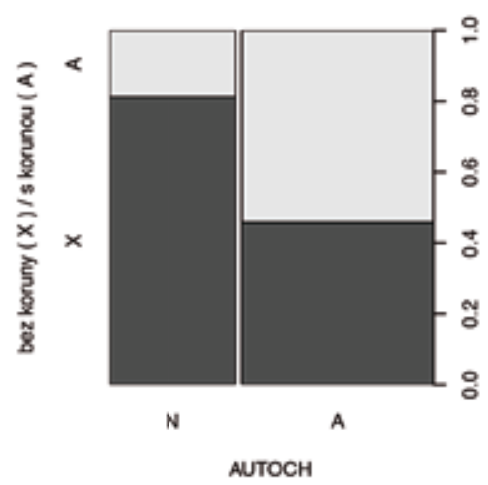

KORYTO2tr

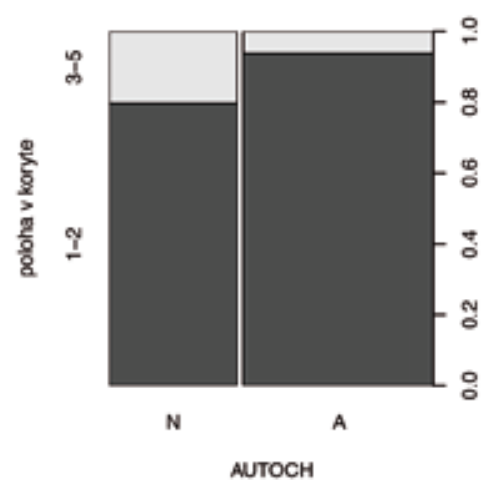

PRUMER

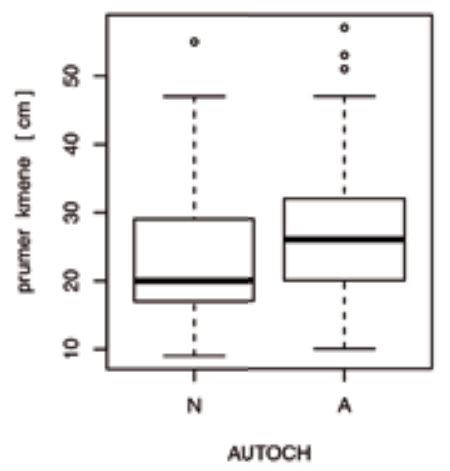

KCRENY

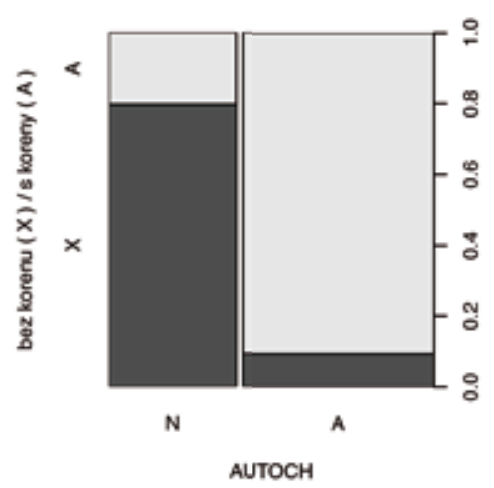

OFIENT1

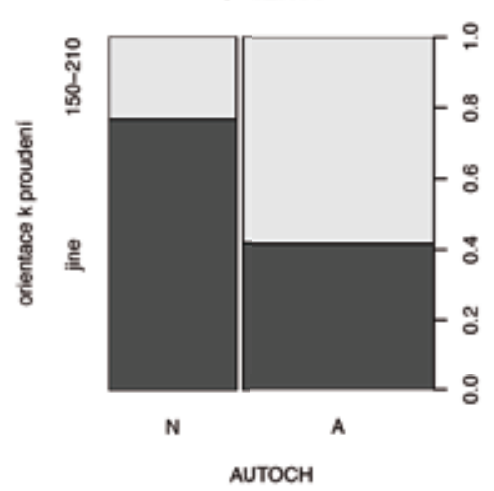

Obr. 2. Popisné charakteristiky řŕčního dřeva pro kusy naplavené (N) a autochtonní (A); krabicový diagram znázorňuje medián, 1-3 kvartil (krabička), maxima a minima (vousy), odlehlé hodnoty jsou zobrazeny kolečky; pro kategoriální proměnné jsou šiřky sloupců úměrné počtu hodnot

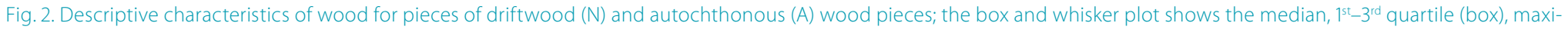
mum and minimum values (whisker), outliers are displayed as circles; for discrete variables the width of columns is proportional to the number of values 
Kmen bez kořenů a zazemnění

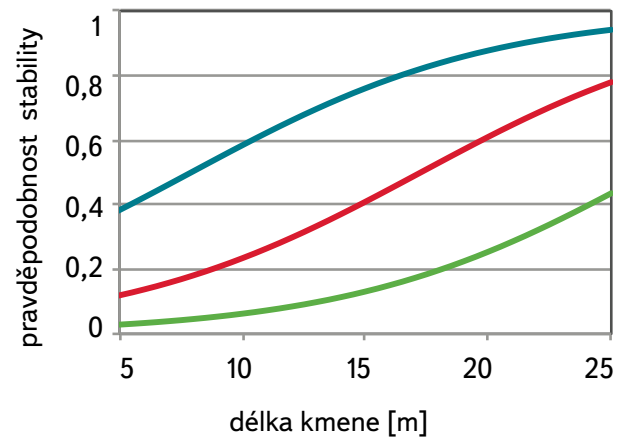

délka kmene [m]
Kmen s kořeny, bez zazemnění

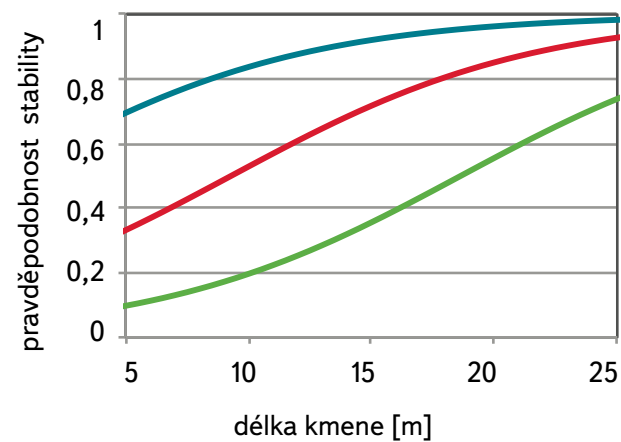

Kmen s kořeny, zazemnění $20 \%$

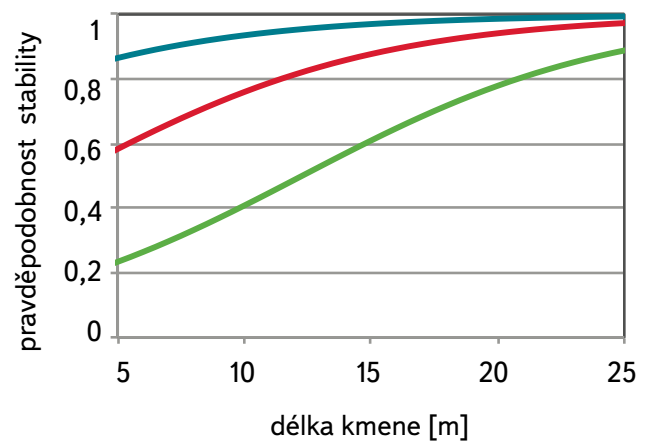

nad hladinou $=0 \mathrm{~cm}$

nad hladinou $=50 \mathrm{~cm}$

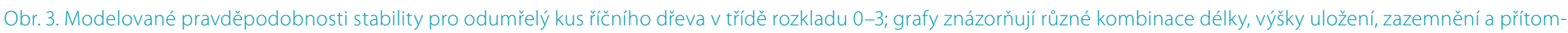
nosti kořenů

Fig. 3. The stability model for a deadwood piece in the decay class $0-3$; the graphs show various combinations of length, log elevation, burial and presence of roots

v korelaci. Z výběru významných a vzájemně nekorelujících popisných charakteristik byl sestaven logistický regresní model. Abychom získali menší skupinu popisných charakteristik se silnou závislostí ke stabilitě, postupně byly z modelu vylučovány proměnné s nejnižší hodnotou významnosti ( $p$ - hodnota). Do výsledného modelu pak byl zařazen výběr nezávislých proměnných s očekávaným silným vlivem na určení stability kmene. Finální model byl ověřen pomocí analýzy reziduí.

Subjektivně hodnocená stabilita byla analyzována odděleně od ostatních proměnných, tedy pouze v univariantním modelu. Dále byla porovnána s výsledky logistického regresního modelu a stanovena míra korelace subjektivního hodnocení a pravděpodobností počítaných modelem. Statistická analýza byla provedena v programu R [21].

Tabulka 2. Statistická významnost závislosti proměnné AUTOCH na popisných charakteristikách v postupných krocích statistické analýzy a regresní koeficienty výsledného modelu (hladiny významnosti $p$ - hodnoty: $\left[{ }^{* * *}\right] p<0,001 ;\left[^{* *}\right] 0,001<p<0,01 ;[*] 0,01<p<0,05$; [nesig.] $p>0,05$ )

Table 2. Statistical significance of the AUTOCH variable on the descriptive characteristics in the sequential steps of statistical analysis and the regression coefficients of the resulting model (significance levels of $p$-value: $\left.{ }^{* * *}\right] p<0.001 ;\left[^{* *}\right] 0.001<p<0.01 ;\left[{ }^{*}\right] 0.01<p<0.05$; [nesig.] $p>0.05$ )

\section{Proměnná (parametr $x$ ) Univariantní model Logistický regresní model}

\section{Logistický regresní model} upravený ( $\left.\beta_{0}=-2,81372\right)$

regresní koeficient $(\beta i)$

\begin{tabular}{|c|c|c|c|c|}
\hline NAD_HL & $* * *$ & nesig. & $* *$ & $-0,03047$ \\
\hline ZAZEM & $* * *$ & ** & * & 0,05184 \\
\hline ZIVY_A & * & nesig. & * & 3,31284 \\
\hline KORUNA_A & $* * *$ & nesig. & vyřazeno & \\
\hline KORENY_A & $* * *$ & * & * & 1,62441 \\
\hline SAMOST_A & $*$ & nesig. & vyřazeno & \\
\hline PRUMER & $*$ & nesig. & vyřazeno & \\
\hline DELKA & $* * *$ & $* * *$ & $* * *$ & 0,16315 \\
\hline ROZKLAD2tr_3.5-5 & nesig. & * & nesig. & 0,24047 \\
\hline KORYTO2tr_3-5 & * & nesig. & vyřazeno & \\
\hline ORIENT1_150-210 & $* * *$ & nesig. & vyřazeno & \\
\hline NAD_HL: ROZKLAD2tr_3.5-5 & nehodnoceno & nehodnoceno & * & 0,03117 \\
\hline STAB_SUBJ & $* * *$ & nehodnoceno & nehodno & \\
\hline
\end{tabular}




\section{VÝSLEDKY}

Na lokalitě bylo popsáno celkem 160 kusư říčního dřeva o délce od 2 do 32 metrů. Toto množství představovalo objem 134,31 m³ na ploše přibližně 1,96 ha. Mezi autochtonní kmeny bylo zařazeno 96 kusů, naplavených kusů bylo 64. Jen 13 případů tvořily živé nebo dožívající stromy, ostatní říční dřevo tvořily odumrelé kusy. Rovných 100 kmenů mělo zachovalé kořeny. Přibližně dvě třetiny rríčního dřeva se vyskytovaly $v$ akumulacích, tedy ve vzájemném kontaktu s alespoň dvěma dalšími kmeny. U většiny kusů Ize předpokládat poměrně dobrou mechanickou pevnost, protože většina říčního dřeva spadala do kategorie kmenů sice již bez kůry, ale dosud s pevným dřevem. Hodnoty četností a průměrné hodnoty pro jednotlivé sledované parametry jsou uvedeny $v$ tabulce 1. Minima a maxima spojitých proměnných Ize dále odečíst z grafů na obr. 2.

Tabulka 2 uvádí výsledek univariantního testování významnosti jednotlivých proměnných pro určení kategorie autochtonní/naplavený kus. Statistická významnost byla jednotlivě prokázána u všech proměnných, kromě stupně rozkladu, kde analýza jen těsně nedosáhla $5 \%$ hladiny statistické významnosti. Vztahy mezi popisnými charakteristikami a proměnnou AUTOCH jsou zobrazeny v grafech na obr. 2. Autochtonní kusy říčního dřeva se vyznačovaly výrazně větší délkou doprovázenou mírně vyšším průměrem kmene. Byly obvykle uloženy $v$ úrovni hladiny nebo pod ní, tedy níže než kmeny naplavené. Střední míra zazemnění se u autochtonních kmenů pohybovala okolo $20 \%$, kdežto u kmenů naplavených byl kontakt s materiálem dna nebo břehů výjimkou. Mezi autochtonními kmeny byl vyšší podíl živých stromů se zachovalou korunou a kořenovým systémem. I když se asi dvě třetiny z celkového počtu kusů řícního dreva vyskytovaly $v$ akumulacích, autochtonní kmeny se nacházely dvakrát častěji samostatně než kmeny naplavené. Téměř $60 \%$ autochtonních kmenů se nacházelo v poloze blízké směru proudění se špičkou směřující po proudu. Mezi naplavenými kmeny se tato vlastnost vyskytovala jen asi v $20 \%$ prípadů. Naprostá většina říčního dřeva se sice vyskytovala v rozsahu vymezeném šiří hladiny za běžných průtoků, pokud se ale nějaké kusy vyskytovaly na břehu, byly to častěji kusy naplavené. Naplavené kusy také častěji než autochtonní spadaly do vyšších tříd stupně rozkladu, ačkoliv převážná většina kusů bylo dřevo mechanicky pevné. Subjektivně byla stabilita většiny naplavených kusů hodnocena známkami 1-3, kdežto mezi autochtonními kmeny převažovaly třídy 6-9, tedy velmi stabilní poloha. Statistická významnost této závislosti byla zároveň jedna z nejvyšších ve srovnání s ostatními charakteristikami.

I když byly popisné charakteristiky zaznamenávány jako nezávislé proměnné, je zřejmé, že některé proměnné spolu mohly korelovat. Korelační matice ukázala významnější korelaci mezi proměnnými NAD_HL a ZAZEM (Pearsonův korelační koeficient $=-0,48)$ a mezi proměnnými DELKA a PRUMER $(0,5)$. U ostatních spojitých proměnných byl korelační koeficient nižší než 0,2. Proměnná PRUMER nebyla nakonec do výsledného modelu zařazena. Druhým přistupem k odhalení korelací mezi popisnými charakteristikami byl výpočet hodnoty VIF (variance inflation factor). Ve všech prípadech nedosahoval hodnoty 3, což je obecně považováno za výsledek, který nesvědčí o významné korelaci mezi proměnnými.

Popisné charakteristiky byly dále testovány logistickým regresním modelem. Jak je vidět z přehledu $v$ tabulce 2 , statisticky významnou popisnou charakteristikou byla délka kmene, míra zazemnění, stupeň rozkladu a př́tomnost kořenů. Těsně za hranicí $5 \%$ statistické významnosti byl vyhodnocen průměr kmene. Abychom snížli počet proměnných $v$ modelu a omezili je na statisticky významné závislosti, upravili jsme model postupným odebíráním proměnných s nejnižší statistickou významností. Zároveň byl do modelu vložen prvek interakce mezi proměnnými NAD_HL a ROZKLAD2tr, která byla zjištěna při kontrole závislostí mezi proměnnými. Interakce je jev, kdy se vlivem jedné proměnné mění směrnice modelovaného vztahu u jiné proměnné. $V$ našem prípadě to konkrétně znamenalo, že mechanicky odolné kmeny z tříd rozkladu 0-3 byly častěji hodnoceny jako autochtonní, pokud se nacházely pod hladinou. Pro částečně zetlelé dřevo v třídách rozkladu 3,5-5 byla závislost opačná - autochtonní kmeny byly uloženy výše nad hladinou než naplavené kusy. V kategorii rozkladu 3,5-5 se nacházelo jen 18 kmenů, tedy $11 \%$ celkového počtu. Logické vysvětlení interakce může vycházet z podmínek na lokalitě. Naplavené dřevo je $v$ korytě téměř vždy uloženo $v$ akumulacích, které jsou za běžných průtoků nad hladinou. Naopak většina autochtonních kmenů se vyskytuje ve vodě v úrovni hladiny nebo pod ní. Toto dřevo zároveň spadá nejčastěji do třídy rozkladu 0-3, protože ponořené dřevo se jen pomalu rozkládá. Naplavené dřevo $v$ akumulacích dobře vysychá, což opět brání rychlému rozkladu. Jiná je situace na březích. Autochtonní i naplavené dřevo zde může ležet v různé výši nad hladinou a zároveň je uloženo ve vlhku, což napomáhá rozkladu. Za vznikem popsané interakce tedy mohou stát vlastnosti říčního dřeva uloženého na březích, kde není rozdíl ve výškovém uložení mezi autochtonními a naplavenými kusy a zároveň jsou všechny zde uložené kmeny náchylnější k rozkladu.

Do výsledného modelu popisujícího vliv popisných charakteristik na určení kmene jako autochtonní či naplavený byly zahrnuty proměnné NAD_HL, ZAZEM, ZIVY, KORENY, DELKA, ROZKLAD2tr a zmíněná interakce NAD_HL: ROZKLAD2tr. Koeficienty $\beta$ a statistickou významnost jednotlivých parametrů modelu zobrazuje tabulka 2. Pomocí vykreslení různých typů reziduí proti nezávislým proměnným a odhadnutým hodnotám byla ověrena platnost modelu. V žádném z prípadů nedocházelo k výraznému odklonu od nuly. Jak bylo popsáno výše, autochtonní kmeny můžeme považovat za stabilní ríční dřevo, naplavené kmeny jsou naopak nestabilní pohyblivou složkou říčního dřeva. Koeficienty $\beta$ a skutečné hodnoty proměnných $x$ pro jednotlivé kusy rríčního dřeva jsme dosadili do rovnice modelu (2) a získali tak pravděpodobnost stability pro každý jednotlivý kus říčního dřeva na lokalitě. V 91 \% př́padů se vypočtená pravděpodobnost stability shodovala s označením kmene za autochtonní kus. Modelovaná stabilita predstavuje hodnotu pravděpodobnosti, s jakou bude kmen stabilní v podmínkách průtoků, které se na lokalitě vyskytly v období předcházejícím terénnímu sběru dat.

Výsledný model logistické regrese umožňuje výpočet pravděpodobnosti odplavení pro kus říčního dřeva s konkrétními parametry. Například kmen o délce 15 metrů uložený v úrovni hladiny zůstane na svém místě s pravděpodobností $41 \%$. Pokud bude mít navíc zachovalé kořeny, stoupne tato pravděpodobnost na $78 \%$. Bude-li navíc v kontaktu se sedimentem na 20 procentech svého povrchu, výsledná pravděpodobnost stability stoupne na $91 \%$. To je pravděpodobnost odplavení kusu říčního dřeva s mediánovými vlastnostmi typického stabilního kmene. Oproti tomu běžný nestabilní kmen o délce šest metrů, bez kořenů, volně uložený ve výšce $0,5 \mathrm{~m}$ nad hladinou zůstane při povodni na původní pozici jen s pravděpodobností 3,4\%. Uvedené pravděpodobnosti platí pro odumřelé kmeny ve třídě rozkladu 0-3. Pro částečně zetlelé kmeny ve třídě rozkladu 3,5-5 by se výsledná pravděpodobnost vlivem interakce NAD_HL:ROZKLAD2tr zvýšila na $17 \%$ u krátkého nestabilního kusu, zatímco u dlouhého kmene s kořeny by zůstala téměř stejná (93\%). Pro odumřelé ríční dřevo ve třídě rozkladu 0-3 jsou pravděpodobnosti stability pro různé kombinace délky, přítomnosti kořenů, uložení nad hladinou a míry zazemnění vyneseny v grafech na obr. 3.

Vypočtené pravděpodobnosti jsme dále použili pro korelaci mezi modelovanou pravděpodobností a subjektivním určením stability $\vee$ proměnné STAB_SUBJ. Modelované hodnoty korelovaly se subjektivním odhadem s koeficientem determinace $\mathrm{R}^{2}=0,57$ (obr. 4). 


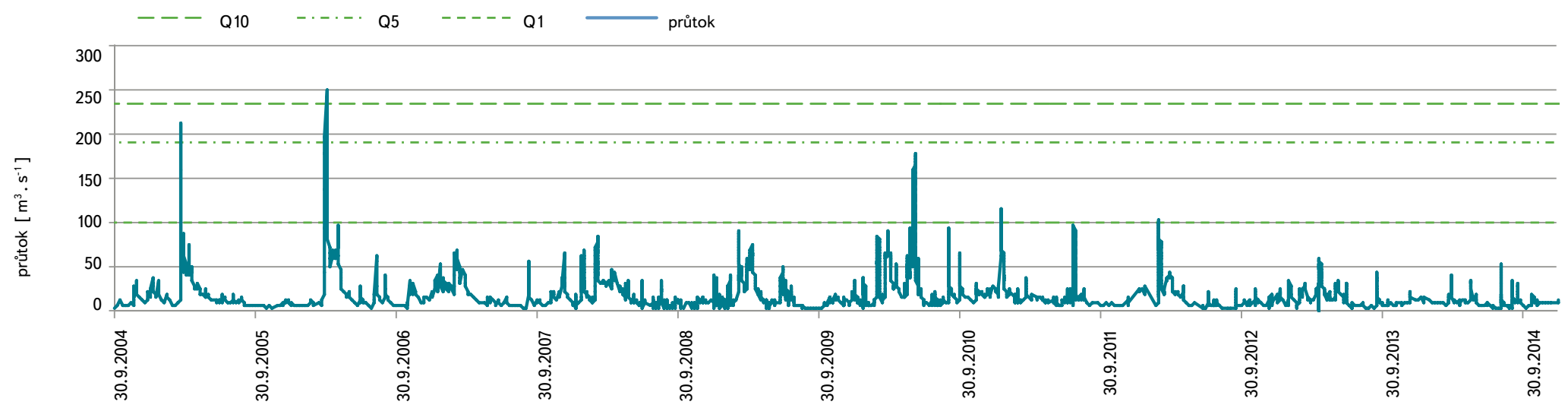

Obr. 5. Průtok na měricí stanici Morava-Moravičany v období let 2004-2014 (zdroj dat: ČHMú)

Fig. 5. Discharge at the Morava-Moravičany gauging station in the period 2004-2014 (source of data: Czech hydrometeorological institute)

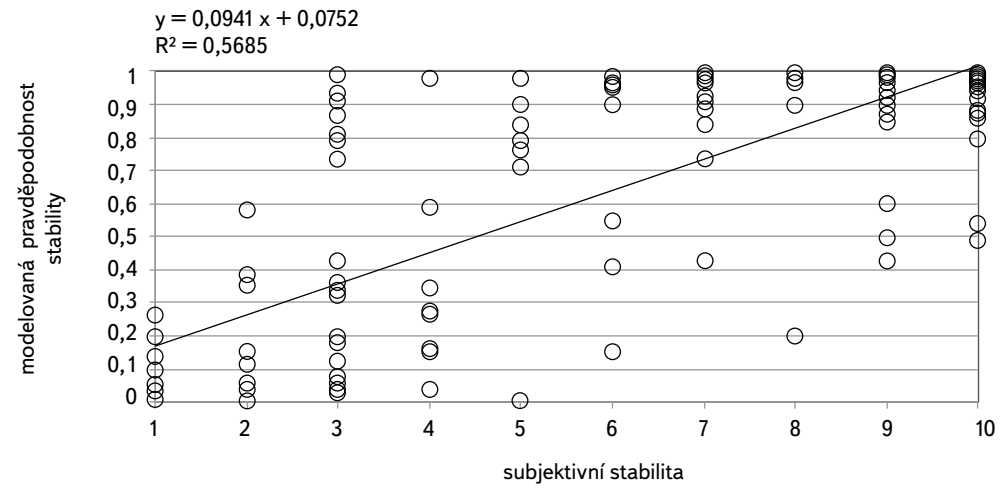

Obr. 4. Korelace subjektivního odhadu stability a modelované pravděpodobnosti stability kusů říčního dřeva

Fig. 4. Correlation of the subjective estimate of stability and modelled probabilities of wood piece stability

\section{DISKUSE}

Metoda pro výpočet stability říčního dřeva použitá v této studii je poměrně netradiční. Většina prací, které se zabývaly terénním výzkumem dynamiky říčního dřeva, pracovala $s$ daty o mobilitě dřeva zjištěné rozdílem $v$ dohledání značených kusů před a po povodni [9, 10, 22-25]. Tyto výsledky jsou sice interpretačně jednoznačné, ale jejich získání je obtížné: dřevo je potřeba nejprve označit a po povodni dohledat. To je časově náročné a naráží to na řadu problémů - po povodni se daři dohledat jen část značených kmenů, což platí i pro kmeny, které zůstaly na místě. To může významně zkreslovat výsledky. Tento problém byl $v$ nedávných letech řešen pomocí sofistikovaných způsobů značení RFID čipy [26], nebo dokonce pomocí vysílaček se zabudovaným GPS přijímačem [12]. Použití takových metod je však stále pracné a neúměrně drahé Hodí se spíše pro základní výzkum obecných zákonitostí pohybu dřeva při zvýšených vodních stavech. Tyto „prímé metody“ navíc vypovídají o mobilitě dřeva při jedné konkrétní povodňové události, jejíž zobecnění je obtížné. Získání dat z prrimých metod je limitováno délkou trvání výzkumných projektů. Pokud nemají výzkumníci výjimečné štěstí, zachytí se svým vzorkem značeného dřeva jen běžnou povodeň odpovídající časovému úseku výzkumu. Oproti tomu zde popsaná metoda je založena na jednorázovém popisu dřeva vyskytujícího se na lokalitě. Obejde se bez značení i zpětného dohledávání dřeva po povodni.
Integruje vliv povodní za delší časové období. Jak dlouhý tento časový úsek může být, závisí zejména na rychlosti zániku říčního dřeva na lokalitě. Pokud se $\checkmark$ minulosti vyskytla významná povodňová událost, je možné naplavené dřevo analyzovat po dobu jeho životnosti. V podmínkách této studie odhadujeme tuto dobu nejméně na pět let, ale velmi pravděpodobně se setkáváme se dřevem starším, zvláště mezi autochtonními kusy. Na obr. 5 je hydrogram blízkého profilu Morava-Moravičany, který je reprezentativní pro Moravu na počátku CHKO Litovelské Pomoraví. V období pěti let před provedením výzkumu prošlo lokalitou několik príbližně jednoletých a jedna pětiletá povodeň. V celém desetiletí, které graf zobrazuje, se vyskytla největší povodeň v roce 2006 s dobou opakování 10-20 let [27]. Úvahy o tom, jestli říční dřevo v roce 2014 mohlo vypovídat ještě o povodni z roku 2006, jsou reálné. Jak bylo popsáno výše, kotvené kmeny, které se na lokalitě vyskytovaly od roku 2003, se do dnešní doby prakticky rozpadly a podobný osud mohl stihnout i zbytky kmenů naplavených do vyšších partií koryta při povodni roku 2006. Na druhou stranu řada zahraničních prací z mírného klimatického pásu uvádí dobu zdržení dřeva v korytě $\checkmark$ desítkách let [4, 28]. Podobně Máčka aj. [29] byli schopni v roce 2009 rozpoznat naplavené a autochtonní ríční dřevo v akumulacích z povodní 2002 a 2006.

Popsanou metodu je možné uplatnit pouze na homogenním úseku řeky po stránce přísunu řičního dřeva. Jestliže porovnáváme naplavené dřevo s autochtonním, měla by existovat alespoň hypotetická možnost naplavení kmenů stejných rozměrů, jako je autochtonní dřevo. V podmínkách lokality byl možný prísun vzrostlých stromů z úseku 500 metrů neupraveného koryta k mostu Mladeč-Nové Zámky a dále z asi 2,5 km dlouhého úseku částečně upraveného koryta až k jezu Řimice. V břehových porostech se vyskytuje podobný vzrostlý porost jako na Vrapači, i když intenzita břehové eroze je díky stabilizaci břehů nižší. V charakteristikách polohy hodnotí metoda vlastnosti naplaveného dřeva „po naplavení". V tom se odlišuje od metod prímého sledování, kdy je hodnocena poloha kusu před odplavením. Lze ale předpokládat, že většina naplaveného dřeva patřila mezi naplavené dřevo i výše v povodí a uvolnila se z podobných pozic, jaké byly popisovány na zkoumané lokalitě. Při hodnocení významu délky kmene není uvažována možná fragmentace během povodně. Takto vzniklé krátké kusy by měly nižší pravděpodobnost stability než kmen původní. Přesto byl tento vliv zanedbán, zejména proto, že k hodnocení možnosti fragmentace jednotlivých kusů nebyly získány žádné údaje. Lze předpokládat, že k rozlámání dochází častěji u říčního dřeva ve vyšším stupni rozkladu. Na lokalitě však převládalo dřevo nezetlelé, což byl druhý důvod, proč nebyla možnost fragmentace zohledněna. 
Podobný př́stup při hodnocení akumulací dřeva použili Máčka aj. [29] v NP Podyjí. Naplavené kusy dřeva se vyznačovaly statisticky významnou kratší délkou a menším průměrem než kmeny autochtonní. Oproti autochtonním kusům postrádaly naplavené kusy kořeny i větve. Abbe a Montgomery [5] popsali stabilní tzv. klíčové kusy akumulací pomocí jejich délky a průměru báze kmene. Na základě těchto dvou parametrů byly stabilní kusy dobře odlišitelné od naplaveného říčního dřeva. Délka stabilních kusů byla obvykle větší než polovina šířky koryta. Průměr báze těchto kmenů byl obvykle větší než polovina hloubky koryta.

Význam rozměrů kmene pro stabilitu byl již popsán $v$ mnoha studiích $z$ terénu i hydraulických laboratoří $[6,10,13]$. Při zobecnění je délka kmene obvykle uváděna relativně vzhledem k širrce koryta. Kmeny s hodnotou blízko 1 a delší jsou považovány za velmi stabilní. V tomto se naše výsledky shodují, nebot’ nejdelší popsané kmeny s délkami 25-30 metrů s vysokou pravděpodobností stability se shoduji délkou s širíi koryta, která je v průměru 28 m. Oproti výsledkům mnoha jiných studií nebyla zjištěna př́liš významná závislost stability na průměru kmene. Je to patrně způsobeno tím, že hloubka vody na lokalitě během zvýšených průtoků presahuje průměr nejsilnějších vyskytujících se kusů. Silnější závislost by mohla být prokázána, pokud by byly měřeny tlouštk'ky bází kmenů nebo nejlépe průměr kořenového systému [5]. Rovněž míra zazemnění a př́tomnost kořenů jsou obecně známé znaky podporující stabilitu kmene [5, 10, 11]. Obě charakteristiky jsou součástí finálního modelu. Oproti tomu př́tomnost koruny (silných větví) a paralelní orientace s proudem byly statisticky významné pouze jednotlivě, ale nikoliv v logistickém regresním modelu v "konkurenci" ostatních charakteristik.

Uložení naplavených kusů v akumulaci říčního dřeva bylo charakteristické pro rozlišenímezi autochtonními a naplavenými kusy, ale statisticky významné pouze v univariantním modelu. Tato vlastnost vychází z povahy naplaveného dřeva, které se při povodni hromadně zachytává na překážkách [3]. Tento vztah nelze jednoduše interpretovat obráceně jako závislost, tedy že dřevo uložené uvnitř akumulací je náchylnější k odplavení. Stabilita akumulace jako celku je závislá na tzv. klíčových kusech, rozměrných kmenech, které leží v jejím základu [5]. Ostatní součásti akumulace, zejména tzv. volné kusy, se mohou při zvýšených vodních stavech snadno mobilizovat. Stabilita jednotlivých prvků akumulace se tedy mưže značně lišit, i když akumulace samotná je stabilní po řadu let. Rozlišení jednotlivých kusů říčního dřeva mezi funkční prvky akumulací však nebylo $v$ této studii provedeno.

Jako novinka mezi identifikovanými vlastnostmi ovlivňujícími stabilitu kmene se jeví význam úrovně uložení kmene vůči běžné hladině. Interpretace je zrejmá. Kmeny vyskytující se po většinu roku pod hladinou jsou nasáklé vodou, jejich specifická hustota je vyšší než hustota vody, což významně snižuje náchylnost k odplavení. Oproti tomu dřevo naplavené na vrcholech akumulací či štěrkových lavic snadno vysychá a zvyšuje tak pravděpodobnost dalšího odplavení. Hustota dřeva je běžně uvažována při modelování pohybu jednotlivých kusů, obvykle v kombinaci s prưměrem kmene [13]. Kombinace těchto hodnot se používá k stanovení tzv. kritické hloubky, při které dochází k odplavení volných kusů dreva. Tento vztah sice dobře funguje v mělkých a sklonitých tocích nižších řádů [10], v hlubokých meandrujících korytech se však uplatňují i jiné mechanismy stabilizace [30]. Zvýšení specifické hustoty dřeva zde působí jako pozitivní zpětná vazba.

Podobným způsobem jako $v$ této studii použili pro analýzu pohyblivosti říčního dřeva logistický regresní model např. Van der Nat aj. [8] na řece Tagliamento v Itálii, Wohl a Goode [10] na horských potocích v Coloradu a Merten aj. [11] na tocích v okolí Hořejšího jezera v USA. Proměnné finálních modelů se liší podle metodik těchto prací a popisovaných charakteristik ríčního dřeva. Van der Nat aj. [8] popsali modelem stabilitu dřevních akumulací v závislosti na velikosti povodně, velikosti akumulace a její poloze. Model Wohl a Goode [10] zahrnoval statisticky významné parametry: délka kmene, průměr kmene a typ uložení (napríč přes koryto, volný, podél břehu). Merten a kol. [11] vyhodnotil v modelu sedm významných faktorů, mezi které patřila délka kmene, zazemnění a př́tomnost kořenů. Podobně jako v této studii použil upravený vzorec logistické regrese pro vykreslení křivek pravděpodobnosti stability pro daný parametr.

Modelované hodnoty pravděpodobnosti samozřejmě nemohou být prijijimány s nekritickou důvěrou. Každý model platí pouze v podmínkách dat, ze kterých byl vytvořen. I když připustíme, že prírodní podmínky na lokalitě Vrapač jsou reprezentativní pro hlavní koryto Moravy v Litovelském Pomoraví, modelované hodnoty by měly být použity spíše pro demonstraci relativního významu jednotlivých popisných charakteristik. Takový príklad může mít význam při vzdělávání pracovníků pověřených údržbou koryta. Z tohoto pohledu je zajímavý vztah znázorněný na obr. 4. Poměrně dobrá míra korelace mezi subjektivně určenou stabilitou rričního dřeva a jejích modelovaných hodnot navozuje myšlenku, že by k základnímu odhadu stability stačilo kvalifikované posouzení pracovníka s místní znalostí.

\section{ZÁVĚR}

Metodou terénního popisu říčního dřeva byly získány charakteristiky typické pro stabilní (autochtonní) kmeny a nestabilní (naplavené) říční dřevo. Jak vyplynulo z univariantního testování jednotlivých proměnných, stabilitu říčního dřeva ovlivňuje řada charakteristik rozměrů, tvaru, mechanických vlastností a uložení dřeva v korytě. Pomocí logistického regresního modelu byly jako charakteristiky nejvýznamnějši pro stabilitu určeny: délka kmene, výška uložení vůči běžné hladině, míra zazemnění, přitomnost kořenů a zda jde o kmen živý či odumřelý. Pokud je z důvodů zachování pririrozeného stavu koryta požadováno ponechání stabilních kusư říčního dřeva, měly by být tyto charakteristiky respektovány. Podobně Ize využít analogii se stabilními kmeny při instalaci záměrně vkládaného dřeva do koryt vodních toků. Konečně modelované pravděpodobnosti stability mohou sloužit k lepšímu poznání dynamiky říčního dřeva na konkrétní lokalitě a získání citu pro terénní odhad stability říčního dřeva.

\section{Poděkování}

Děkuji pracovníkům Správy CHKO Litovelské Pomoraví, zejména paní Olze Žerničkové za vstřícnost při zajištěni terénniho výzkumu a Janě Timkové z firmy DataTalk za pomoc se statistickou analýzou.

\section{Literatura}

[1] MÁČKA, Z., KREJČĺ, L., GRYC, V., HALAS, P., KOLÁŘ, T., KOLÁŘOVÁ, N. a VAVRČÍK, H. Říční dřevo ve vodnich tocich ČR. Brno: Masarykova univerzita, 2011. $107 \mathrm{~s}$.

[2] GREGORY, S.V., BOYER, K.L., and GURNELL, A.M. The Ecology and Management of Wood in World Rivers. American Fisheries Society, Symposium 37. Bethesda, Maryland, 2003, 432 p.

[3] PIÉGAY, H. Nature, mass and preferential sites of coarse woody debris deposits in the Lower Ain Valley (Mollon Reach), France. Regulated Rivers: Research \& Management, 1993, 8(4), p. 359-372.

[4] HYATT, T.L. and NAIMAN, R.J. The residence time of large woody debris in the Queets River, Washington, USA. Ecological Applications, 2001, 11(1), p. 191-202.

[5] ABBE, T.B. and MONTGOMERY, D.R. Patterns and processes of wood debris accumulation in the Queets river basin, Washington. Geomorphology, 2003, 51(1-3), p. 81-107.

[6] LIENKAEMPER, G.W. and SWANSON, F.J. Dynamics of large woody debris in old-growth Douglas-fir forests. Canadian Journal of Forest Research, 1987, 17(2), p. 150-156.

[7] ELOSEGI, A., DIEZ, J.R., and POZO, J. Abundance, characteristics, and movement of woody debris in four Basque streams. Archiv für Hydrobiologie, 1999, 144(4), p. 455-471.

[8] VAN DER NAT, D., TOCKNER, K., EDWARDS, P.J., and WARD, J.V. Large wood dynamics of complex Alpine river flood plains. Journal of the North American Benthological Society, 2003, 22(1), p. 35-50.

[9] WARREN, D.R. and KRAFT, C.E. Dynamics of large wood in an eastern U.S. mountain stream. Forest Ecology and Management, 2008, 256(4), p. 808-814. 
[10] WOHL, E. and GOODE, J.R. Wood dynamics in headwater streams of the Colorado Rocky Mountains. Water Resources Research, 2008, 44: W09429.

[11] MERTEN, E., FINLAY, J., JOHNSON, L., NEWMAN, R., STEFAN, H., and VONDRACEK, B. Factors influencing wood mobilization in streams. Water Resources Research, 2010, 46: W10514.

[12] RAVAZZOLO, D., MAO, L., PICCO, L., and LENZI, M.A. Tracking log displacement during floods in the Tagliamento River using RFID and GPS tracker devices. Geomorphology, 2015, 228, p. 226-233.

[13] BRAUDRICK, C.A., GRANT, G.E., ISHIKAWA, Y., and IKEDA, H. Dynamics of wood transport in streams: A flume experiment. Earth Surface Processes and Landforms, 1997, 22(7), p. 669-683.

[14] BOCCHIOLA, D., RULLI, M.C., and ROSSO, R. Transport of large woody debris in the presence of obstacles. Geomorphology, 2006, 76(1-2), p. 166-178.

[15] ALLEN, D., ARTHUR, S., HAYNES, H., WALLIS, S.G., and WALLERSTEIN, N. Influences and drivers of woody debris movement in urban watercourses. Science China-Technological Sciences, 2014, 57(8) p. 1512-1521.

[16] RUIZ-VILLANUEVA, V., BLADE, E., SANCHEZ-JUNY, M., MARTI-CARDONA, B., DIEZ-HERRERO, A., and MARIA BODOQUE, J. Two-dimensional numerical modeling of wood transport. Journal of Hydroinformatics, 2014, 16(5), p. 1077-1096.

[17] SCHMOCKER, L., HUNZIKER, R., MUELLER, U., and WEITBRECHT, V. Driftwood retention in pre-alpine rivers. In: Schleiss, A. J., Speerli, J., Pfammatter, R. (ed.) Swiss Competences in River Engineering and Restoration, 2014, p. 117-127.

[18] GSCHNITZER, T., GEMS, B., AUFLEGER, M., MAZZORANA, B., and COMITI, F. On the Evaluation and Modelling of Wood Clogging Processes in Flood Related Hazards Estimation. In: Lollino, G., Arattano, M., Rinaldi, M., Giustolisi, O., Marechal, J. C., Grant, G. E. (ed.) Engineering Geology for Society and Territory, Vol 3: River Basins, Reservoir Sedimentation and Water Resources, 2015, p. 139-142.

[19] KOŽENÝ, P., VAJNER, P., ŽERNÍČKOVÁ, O., ŠINDLAR, M. a ZAPLETAL, J. Vývoj technické stabilizace dřevní hmoty v korytě Moravy v CHKO Litovelské Pomoraví. Vodní hospodárství, 2011, (3), s. 125-129.

[20] HENDL, J. Prehled statistických metod zpracování dat: analýza a metaanalýza dat. Portál. Praha $2006,583 \mathrm{~s}$.

[21] R DEVELOPMENT CORE TEAM. R: A language and environment for statistical computing. R Foundation for Statistical Computing, Vienna, Austria, 2008. ISBN 3-900051-07-0, URL http://www.R-project.org.

[22] BENKE, A.C. and WALLACE, J.B. Wood Dynamics in Coastal Plain Blackwater Streams. Canadian Journal of Fisheries and Aquatic Sciences, 1990, 47(1), p. 92-99.

[23] BERG, N., CARLSON, A., and AZUMA, D. Function and dynamics of woody debris in stream reaches in the central Sierra Nevada, California. Canadian Journal of Fisheries and Aquatic Sciences, 1998, 55(8), p. 1807-1820.

[24] MAO, L., BURNS, S., COMITI, F., ANDREOLI, A., URCIUOLO, A., GAVIÑO-NOVILLO, et. al. LW jams in a mountain stream of Tierra del Fuego: Piece movement and hydro-morphological effects analysis. Bosque, 2008, 29(3), p. 197-211.

[25] KOŽENÝ, P. Large wood dynamics in the channel and floodplain of the Blanice stream during an one in ten years flood. In: Šustr, P. (ed.) Aktuality šumavského výzkumu IV. Správa NP a CHKO Šumava, 2010, s. 51-53.

[26] MACVICAR, B.J., PIEGAY, H., HENDERSON, A., COMITI, F., et. al. Quantifying the temporal dynamics of wood in large rivers: field trials of wood surveying, dating, tracking, and monitoring techniques. Earth Surface Processes and Landforms, 2009, 34(15), p. 2031-2046.

[27] ANONYM. Zpráva o hydrologickém vyhodnocení jarní povodně 2006 na území ČR. Praha: Český hydrometeorologický ústav, 2006, 86 s.

[28] WALLACE, J.B., WEBSTER, J.R., EGGERT, S.L., MEYER, J.L., and SILER, E.R. Large woody debris in a headwater stream: Long-term legacies of forest disturbance. International Review of Hydrobiology, 2001, 86(4-5), p. 501-513.

[29] MÁČKA, Z., KREJČI, L., a LOUČKOVÁ, B. Prostorová distribuce a vlastnosti dřevních akumulací jako indikátory transportu a depozice hrubého říčního dřeva - př́padová studie z řeky Dyje na česko-rakouském pomezí. Thayensia, 2011, (8), p. 27-56.

[30] CURRAN, J.C. Mobility of large woody debris (LWD) jams in a low gradient channel. Geomorphology, 2010, 116(3-4), p. 320-329.

\section{Autor}

Mgr. Pavel Kožený

凶pavel_kozeny@vuv.cz

Výzkumný ústav vodohospodářský T. G. Masaryka, v. v. i.

\section{CHARACTERISTICS DETERMINING THE STABILITY OF WOODY DEBRIS ON THE EXAMPLE OF MORAVA RIVER IN THE LITOVELSKÉ POMORAVÍ}

\section{KOZENY, P.}

TGM Water Research Institute, p. r. i.

Keywords: woody debris - floods - Morava River Litovelské Pomoraví PLA - logistic regression

Wood is an important part of streams, affecting their hydraulic, morphological and biological features. For the stream management and flood risk reduction it is important to know the characteristics that increase the stability of wood and prevent its flushing at high water stages. By the analysis of 160 pieces of woody debris in the Morava River in Litovelské Pomoraví PLA the features important for wood stability in this area were identified. The analysis by the logistic regression model identified statistical significance of the following characteristics: log length, elevation according to the common water level, burial, presence of roots and whether the piece is living or dead. Application of the model to a specific wood piece enables to calculate modelled probability of stability. If the aim is to maintain stable wood in stream according to the natural status of stream, these characteristics should be respected. The stability probabilities of the model correlated with subjective probability estimate with the coefficient of determination $\mathrm{R}^{2}=0.57$.

Příspěvek prošel lektorským řízením. 